\title{
Silage quality of pearl millet cultivars produced in different cutting ages
}

\section{Qualidade da silagem de cultivares de milheto produzidas em diferentes idades de corte}

\author{
Kátia Aparecida de Pinho Costa ${ }^{1 *}$; Itamar Alves Guerra Filho²; \\ Renato Lara de Assis ${ }^{3}$; Kátia Cylene Guimarães ${ }^{1}$; Welma Santos Cruvinel2; \\ Patrícia Soares Epifânio ${ }^{4}$; Rodrigo Rodrigues Gouveia ${ }^{5}$
}

\begin{abstract}
The millet has being prominent in recent years, especially with the arrival of early genotypes with high nutritional value and productive potential, coming from breeding. As these genotypes are new, little information exists about them. Thus, it is important to obtain technical information, supported by scientific studies about the behavior of these materials considering the nutritional value and harvest for silage production. The objective of this research was to evaluate the silage quality of pearl millet genotypes grown in different cuts age. The experiment was carried out on the campus of the Agronomy, of the Rio Verde University. The experimental design was randomized blocks with four replications in a 5 x 3 factorial, with five genotypes of millet: ARD 500, ADR 7010, LAB 0730, LAB 0731 and LAB 0732 and three cuts ages: 57, 65 and 73 days after sowing (DAS). The results showed that silages produced by millet, regardless of genotype, could be considered of nutritional value. Since this is a precocious material the best age that provided the best quality of these silages was when the materials were harvested at 57 DAS.
\end{abstract}

Key words: Soluble carbohydrates, fibrous fraction, $\mathrm{pH}$

\section{Resumo}

O milheto vem ganhando destaque nos últimos anos, principalmente com a chegada de genótipos precoces e de alto valor nutritivo e potencial produtivo, oriundos do melhoramento genético. Por se tratarem de materiais novos, existem poucas informações sobre esses genótipos. Nesse sentido, é importante obter informações técnicas, apoiadas em estudos científicos, sobre o comportamento desses materiais em relação ao valor nutritivo e época de colheita para a produção de silagens. Diante disso, objetivou-se avaliar a qualidade de silagem de genótipos de milheto produzidas em diferentes idades de cortes. O experimento foi conduzido no Campus da Faculdade de Agronomia da Universidade de Rio Verde. O delineamento experimental utilizado foi de blocos ao acaso, com quatro repetições, em esquema fatorial $5 \times 3$, sendo, cinco cultivares de milheto: ARD 500, ADR 7010, LAB 0730, LAB 0731 e LAB 0732 e três idades de cortes: 57, 65 e 73 dias após a semeadura (DAS). Os resultados mostraram que as silagens produzidas por milheto, independente do genótipo, podem ser consideradas de boa qualidade. Por se tratar de materiais precoces a melhor idade que proporcionou melhor qualidade da silagem desses materiais, foi quando os materiais foram colhidos aos 57 DAS.

Palavras-chave: Carboidrato solúvel, frações fibrosas, $\mathrm{pH}$

\footnotetext{
1 Profs. Pesquisadores, Instituto Federal Goiano, Campus Rio Verde, Rio Verde, GO.E-mail: katiazoo@hotmail.com; katiacefetrv@, hotmail.com

2 Discente(s) da Universidade de Rio Verde, Rio Verde, GO. E-mail: itamarguerra@live.com; welmacruvinel@hotmail.com

3 Prof. Pesquisador, Instituto Federal Goiano, Campus Iporá, Iporá, GO. E-mail: relassis@bol.com.br

4 Prof a do Instituto Federal Goiano, Extensão Quirinópolis, GO. Quirinópolis, GO. E-mail: patyepifanio@yahoo.com.br

5 Discente do Instituto Federal Goiano, Campus Rio Verde, Rio Verde, GO. E-mail: gouveia_rr@hotmail.com

Author for corespondence
} 


\section{Introduction}

The forage production in the tropics, particularly in central Brazil, is characterized by periods of high production that are quantitatively and qualitatively superior, and also for periods with lower production volumes and lower quality. This occurrence is due to the decreased of light availability, temperature and rainfall at certain times of the year.

These instances are responsible for low productivity levels of livestock nationwide, because it prevents the forage to growth uniformly through the year. In choosing alternatives to minimize the effects of grass seasonal production, must be taken into account the farm level. In this sense, the preservation technique of fodder has been adopted as a strategy to address the forage shortage during this critical period of the year.

Among the various forage species that can be used by producers, pearl millet [Pennisetum glaucum (L.) R. Brown] has been explored as an alternative for that period by presenting agronomic characteristics of high drought resistance, wide adaptation and high yield mass. Coupled with the rapid growth, the species deserves attention for silage production with quality, being able to produce additional food in quantity and quality satisfactory during this time of year (GUIMARÃES JUNIOR et al., 2008).

Because of its great adaptation to the Cerrado biome, millet is gaining prominence in recent years, especially with the arrival of early and high yield potential genotypes, coming from breeding. This meant that this plan ceased to be a simple kind of coverage or straw production for tillage, being considered a culture of economic value for forage and silage in this region (DAN et al., 2009).

Because these are new materials, little information exists on these genotypes. Thus, it is important to obtain technical information, supported by scientific studies on the behavior of these materials in relation to nutritional value and harvest time for silage production. The objective was to evaluate the silage quality of pearl millet genotypes grown in different age cuts.

\section{Material and Methods}

The experiment was carried out on the campus of Agronomy Faculty - Fesurv - University of Rio Verde, which is located on the farm sources of knowledge, at $748 \mathrm{~m}$ of altitude, $17^{\circ} 48$ 'south latitude and $50^{\circ} 55^{\prime}$ 'west longitude. The soil was classified as distroferric red latossol, with $600 \mathrm{~g} \mathrm{~kg}^{-1}$ of clay, $350 \mathrm{~g} \mathrm{~kg}^{-1}$ of silt and $50 \mathrm{~g} \mathrm{~kg}^{-1}$ of sand. The chemical characteristics of soil at $0-20 \mathrm{~cm}$ before planting were: $\mathrm{pH}$ in water: $4.8, \mathrm{Ca}: 1.11 \mathrm{cmol} \mathrm{dm}^{-3}$, Mg: $0.39 \mathrm{cmol} \mathrm{dm}^{-3}, \mathrm{Al}: 0,10 \mathrm{cmol} \mathrm{dm}^{-3}, \mathrm{Al}+\mathrm{H}: 5.0$ cmol dm${ }^{-3}, \mathrm{~K}: 0.18 \mathrm{cmol} \mathrm{dm}^{-3}$; CTC: $6.64 \mathrm{cmol} \mathrm{dm}^{-3}$, P: $8.17 \mathrm{mg} \mathrm{dm}^{-3}, \mathrm{Cu}: 3.7 \mathrm{mg} \mathrm{dm}^{-3}, \mathrm{Zn}: 1.8 \mathrm{mg} \mathrm{dm}^{-3}$, Fe: $83.2 \mathrm{mg}^{-3}$, MO: $31.26 \mathrm{~g} \mathrm{dm}^{-3}$.

The area preparation was done by eliminating invasive plants, applying glyphosate at a dosage of $1458 \mathrm{~g} \mathrm{ha}^{-1}$. Fifteen days after desiccation was used 1.0 ton of lime, with 95\% PRNT, and subsequently was made a harrowing, followed by leveling. The genotypes of pearl millet [Pennisetum glaucum (L.) R. Br] were established on March 9, 2009, where they were sown manually on ground already furrowed and fertilized with $250 \mathrm{~kg} \mathrm{ha}^{-1}$ of formulation 2-20-19 (NPK). There were used 6 lines of $10 \mathrm{~m}$ for each genotype, spaced $0.5 \mathrm{~m}$ between rows. The quantities of seed used were 12 $\mathrm{kg} \mathrm{ha}^{-1}$, aiming to reach a density of 250,000 plants $\mathrm{ha}^{-1}$. The nitrogen $\left(80 \mathrm{~kg} \mathrm{ha}^{-1} \mathrm{~N}\right)$ was performed 30 days after seeding, topdressing, using as source the ammonium sulfate.

The experimental design was randomized blocks with four replications in a $5 \times 3$ factorial, being five varieties of millet: $\mathrm{ADR}$ 500, $\mathrm{ADR}$ 7010, LAB 0730, LAB 0731 and LAB 0732 and three cuts ages: 57, 65 and 73 days after sowing (DAS), totaling 60 experimental plots.

For the ensiling process, the pearl millet genotypes were harvested on days 12, 19 and 26 May 2009, which are correlated with the cutting ages of 57, 65 and 73 DAS, respectively. The dry matter contents of the materials before ensiling are shown in Table 1. 
Table 1. DM (\%) contents of millet genotypes before the ensiling process.

\begin{tabular}{lccc}
\hline \multirow{2}{*}{ Millet Genotypes } & \multicolumn{3}{c}{ Cuts Ages (DAS) } \\
\cline { 2 - 4 } & $\mathbf{5 7}$ & $\mathbf{6 5}$ & $\mathbf{7 3}$ \\
\hline ADR 500 & 24.12 & 26.53 & 32.08 \\
ADR 7010 & 24.54 & 26.12 & 33.13 \\
LAB 0730 & 26.02 & 27.11 & 36.42 \\
LAB 0731 & 24.13 & 27.51 & 36.14 \\
LAB 0732 & 25.94 & 25.06 & 35.11 \\
\hline
\end{tabular}

Source: Elaboration of the authors.

The materials were collected with a knife, close to the ground. Subsequently were minced, in particles of 10 to $30 \mathrm{~mm}$. Then the materials were stored in silos of PVC, measuring $10 \mathrm{~cm}$ in diameter and $40 \mathrm{~cm}$ in length. The specific mass of silo was of $1.12 \mathrm{~kg} \mathrm{dm}^{3}$. The ensiled material was packed with iron pendulum and the silos were sealed with PVC caps, fitted with Bunsen valves and sealed with tape. Once closed, the silos were placed in a tilted position, to facilitate the exit of effluents by Bunsen valve, simulating a trench silo.

After 60 days, the silos were opened, discarding the top and bottom portion of each. The central portion of the silo was homogenized and placed in plastic trays. After opening the silos, there were determined the $\mathrm{pH}$ values, using a potentiometer Expandomatic Beckman SS-2. Later these materials were weighed and submitted to forced ventilation in oven at $55^{\circ} \mathrm{C}$ for 96 hours for determination of pre-dried matter. The samples were ground in a mill Willey-type with a mesh sieve of $1 \mathrm{~mm}$, for further analysis.

The chemical analyzes were performed to determine the levels of dry matter (DM), crude protein (CP), neutral detergent fiber (NDF), acid detergent fiber (ADF), lignin, cellulose, hemicellulose and soluble carbohydrates using the method described by Silva and Queiroz (2002). The total digestible nutrient (TDN) was calculated through the NDF content using the equation: NDT $=105.2-0.68(\mathrm{FDN})$ proposed by Chandler (1990).

The results were subjected to analysis of variance by the statistical program SISVAR 4.6 (FERREIRA, 2000) and means were compared by Tukey test at level of $5 \%$ of probability.

\section{Results and Discussion}

Analysis of variance showed no significant effect in DM, CP, NDF, ADF, lignin, hemicellulose, TDN, $\mathrm{CHO}$ soluble content and $\mathrm{pH}$ values for silages of pearl millet genotypes considering genotype and cuts age. However, there was a significant effect, isolated for all these variables, to the cuts ages.

It is noted that in Table 2 for all evaluated genotypes, there was an increase in DM content with increasing of cuts ages, where the highest concentrations were obtained at the age of 73 DAS, differing from the ages of 57 and 69 DAS. Studying the quality and nutritional value of three cultivars of millet harvested at different ages, Amaral et al. (2008) found DM of 21.34, 36.83 and $27.7 \%$ for ages 70, 90 and $110 \mathrm{DAS}$, respectively. These levels were similar to those found in this study.

The assessment of DM content of silage is of fundamental importance because, when the silage reaches values above $35 \%$ of dry matter, compaction is difficult, reducing the air elimination of silage and creating conditions for heating and mold development. In contrast, the plants fermentation excessively humid provides environment for clostridial fermentation, resulting in high levels of butyric acid and low intake by animals (BORGES; GONÇALVES; RODRIGUEZ, 1997). 
In Table 2 it is observed that increasing cuts LAB 0732. As for the genotype ADR 7010, the ages ages for ensiling process decreases the $\mathrm{CP}$ of silage of 57 and 65 were similar, and only at 73 DAS there from genotypes ADR 50, LAB 0730, LAB 0731 and was a reduction in crude protein content.

Table 2. Dry matter, crude protein, total digestible nutrient, soluble carbohydrates content and $\mathrm{pH}$ values of millet genotypes ensiled with three different cuts ages.

\begin{tabular}{|c|c|c|c|}
\hline \multirow{2}{*}{ Millet Genotypes } & \multicolumn{3}{|c|}{ Cuts Ages (DAS) } \\
\hline & 57 & 65 & 73 \\
\hline & \multicolumn{3}{|c|}{ Dry matter content $(\%)$} \\
\hline ADR 500 & $25.32 \mathrm{~b}$ & $27.83 \mathrm{~b}$ & $32.91 \mathrm{a}$ \\
\hline ADR 7010 & $25.74 \mathrm{~b}$ & $27.42 \mathrm{~b}$ & $34.03 \mathrm{a}$ \\
\hline LAB 0730 & $26.58 \mathrm{~b}$ & $27.63 \mathrm{~b}$ & $37.12 \mathrm{a}$ \\
\hline LAB 0731 & $25.61 \mathrm{~b}$ & $28.48 \mathrm{~b}$ & $37.04 \mathrm{a}$ \\
\hline LAB 0732 & $26.10 \mathrm{~b}$ & $25.80 \mathrm{~b}$ & $35.72 \mathrm{a}$ \\
\hline Average & 25.91 & 27.43 & 35.36 \\
\hline \multirow[t]{2}{*}{ CV $(\%)$} & \multicolumn{3}{|c|}{ 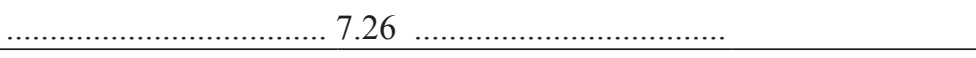 } \\
\hline & \multicolumn{3}{|c|}{$\begin{array}{ll}\text { Crude protein content }(\%) \\
\end{array}$} \\
\hline ADR 500 & $13.12 \mathrm{a}$ & $11.88 \mathrm{~b}$ & $9.37 \mathrm{c}$ \\
\hline ADR 7010 & $12.50 \mathrm{a}$ & $11.67 \mathrm{a}$ & $8.75 \mathrm{~b}$ \\
\hline LAB 0730 & $12.33 \mathrm{a}$ & $11.25 \mathrm{~b}$ & $9.17 \mathrm{c}$ \\
\hline LAB 0731 & $12.53 \mathrm{a}$ & $11.35 \mathrm{~b}$ & $9.21 \mathrm{c}$ \\
\hline LAB 0732 & $12.20 \mathrm{a}$ & $11.12 \mathrm{~b}$ & $8.54 \mathrm{c}$ \\
\hline Average & 12.53 & 11.45 & 9.00 \\
\hline \multirow{2}{*}{ CV (\%) } & & $\ldots 7.23$ & \\
\hline & \multicolumn{3}{|c|}{ Total digestible nutrient content $(\%)$} \\
\hline ADR 500 & $61.46 \mathrm{c}$ & $65.39 \mathrm{~b}$ & $72.78 \mathrm{a}$ \\
\hline ADR 7010 & $63.00 \mathrm{~b}$ & $64.73 \mathrm{~b}$ & $72.85 \mathrm{a}$ \\
\hline LAB 0730 & $59.19 \mathrm{c}$ & $66.02 \mathrm{~b}$ & $70.37 \mathrm{a}$ \\
\hline LAB 0731 & $63.23 \mathrm{c}$ & $67.48 \mathrm{~b}$ & $72.60 \mathrm{a}$ \\
\hline LAB 0732 & $63.13 \mathrm{c}$ & $76.48 \mathrm{~b}$ & $72.60 \mathrm{a}$ \\
\hline Average & 62.06 & 68.02 & 72.24 \\
\hline \multirow[t]{2}{*}{ CV (\%) } & & .. $3.29 \quad \ldots$ & $\ldots$ \\
\hline & \multicolumn{3}{|c|}{ Soluble carbohydrate content (\%) } \\
\hline ADR 500 & $4.31 \mathrm{a}$ & $3.89 \mathrm{~b}$ & $2.89 \mathrm{~b}$ \\
\hline ADR 7010 & $4.30 \mathrm{a}$ & $3.41 \mathrm{~b}$ & $2.62 \mathrm{c}$ \\
\hline LAB 0730 & $4.25 \mathrm{a}$ & $3.58 \mathrm{~b}$ & $2.46 \mathrm{c}$ \\
\hline LAB 0731 & $4.19 \mathrm{a}$ & $3.40 \mathrm{~b}$ & $2.53 \mathrm{c}$ \\
\hline LAB 0732 & $4.03 \mathrm{a}$ & $3.16 \mathrm{~b}$ & $2.60 \mathrm{~b}$ \\
\hline Average & 4.21 & 3.48 & 2.62 \\
\hline \multirow[t]{2}{*}{ CV (\%) } & & $9.10 \quad \ldots$ & \\
\hline & & pH values & \\
\hline ADR 500 & $3.56 \mathrm{~b}$ & $3.93 \mathrm{~b}$ & $4.26 \mathrm{a}$ \\
\hline ADR 7010 & $3.66 \mathrm{~b}$ & $3.90 \mathrm{~b}$ & $4.30 \mathrm{a}$ \\
\hline LAB 0730 & $3.64 \mathrm{~b}$ & $3.76 \mathrm{~b}$ & $4.23 \mathrm{a}$ \\
\hline LAB 0731 & $3.86 \mathrm{~b}$ & $3.93 \mathrm{~b}$ & $4.43 \mathrm{a}$ \\
\hline LAB 0732 & $3.54 \mathrm{~b}$ & $3.86 \mathrm{~b}$ & $4.30 \mathrm{a}$ \\
\hline Average & 3.65 & 3.87 & 4.30 \\
\hline CV (\%) & 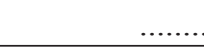 & 13.86 & \\
\hline
\end{tabular}

Means followed by different letters with lower case in line (age cuts), differs by Tukey test $(\mathrm{P}<0.05)$.

Source: Elaboration of the authors. 
The CP content of silages obtained in this study at 73 DAS were similar to those found by Guimarães Junior et al. (2005b), that working with silage of different pearl millet genotypes harvested at $82 \mathrm{DAS}$, found crude protein of $10.15,11.32$ and $9.73 \%$ at 56 days of fermentation, for CMS-1, BRS 1501 and BN-2 cultivars, respectively. These authors reported that the $\mathrm{CP}$ in this study are higher than those normally found in fresh plant and silages of other crops used for silage production, indicating that the nutritional value of millet silage is higher when related to its protein content

Guimarães Junior et al. (2008) reported that although the energy content of pearl millet grain is lower than corn and sorghum, it has high protein content, which explains the millet is recommended as an interesting option for ensiling process.

A food and/or a diet should contain at least $7 \% \mathrm{CP}$ to provide sufficient nitrogen for effective microbial fermentation in rumen. In this work it is observed in Table 2, that even the silage harvested at 73 DAS showed levels above the critical level of $7 \%$ which account satisfactorily for minimum protein requirements of ruminants (VAN SOEST, 1994).

The composition of total digestible nutrients is indicative of foods energy content and their determination in silage or food is essential for the balancing and optimization of diets (CAPPELLE et al., 2001). The lower TDN levels were observed in silages harvested at 57, which differed from silages harvested at 65 and 73 DAS, except for ADR 7010, which showed similar TDN levels harvested at ages of 57 and 65 DAS. It is noteworthy that the TDN levels were estimated from the NDF, and thus the highest concentrations of TDN are necessarily recorded in the silage harvested at 73 DAS, which showed the highest NDF levels (Table 2). Van Soest (1994) explains that many factors such as strain, temperature, light intensity, water availability, latitude, maturity, type of harvest, affect the chemical composition and, consequently, the availability of energy from food.
Cappelle et al. (2001) reported that estimates of energy values of foods and diets are important for animals with high production, especially for dairy cows, which require large amounts of energy. Diets deficient in energy reduces the milk production, causing excessive weight loss, reproductive problems and may reduce resistance to disease.

As age increased from 57 to 73 DAS, there was reduction in levels of soluble carbohydrates for silage of ADR 7010, LAB 7030 and 7031. As for ADR 500 and LAB 7030 the levels of soluble carbohydrates were similar when harvested at 65 and 73 DAS, differing only from the age of 57 DAS (Table 2).

Regardless of the evaluated genotypes the average of soluble carbohydrates levels were 4.21 , 3.48 and $2.62 \%$ for the cuts ages of 57,65 and 73 DAS, respectively. According to Nussio, Campos and Dias (2001), the levels of soluble carbohydrates in the forage being ensiled contribute to a good fermentation increasing the production of organic acids, where the minimum content of soluble carbohydrates should be of 3\%. Although millet have better protein content in silage (GUIMARÃES JUNIOR et al., 2008), this culture has lower levels of soluble carbohydrates when compared with the culture of corn and sorghum. Guimarães Júnior et al. (2005c), studying silages of three millet cultivars, found that there was difference between the materials with respect to soluble carbohydrates ranged from $8.33 \%$ for $\mathrm{BN}-2,5.75 \%$ for $\mathrm{CMS}-1$ and $2.59 \%$ for BRS- 1501 .

The $\mathrm{pH}$ values increased in proportion to increased cuts ages, spending an average of 3.65 to 4.30 when harvested at 57 and 73 DAS, respectively. This increase possibly occurred due to the reduction in crude protein content, of silage harvested at 73 DAS, probably because greater protein degradation and its attendant products resulting from degradation (amino acids, amines and ammonia) have hampered the rapid drop in $\mathrm{pH}$, without, however, affect the silage at these ages (McDONALD; HENDERSON; 
HERON, 1991), because it is within the proper range (3.8 to 4.2 ), where did not turn possible undesirable secondary fermentations (JAYME et al., 2009).

McDonald, Henderson and Heron (1991) reported that the final $\mathrm{pH}$ of silage is an indicative of the quality of the fermentation process, and its value inside the silo must become, as quickly as possible, low enough to inhibit the growth of undesirable bacteria, such as the gender Clostridium.

Amaral et al. (2008) studying the quality and nutritional value of three cultivars of millet harvested at different ages, found $\mathrm{pH}$ values of 3.48, 3.62 and 3.77 for ages of 70, 90 and $110 \mathrm{DAS}$, respectively.

The NDF expresses the forage quality which is composed of structural carbohydrates that are mostly utilized by ruminants, mainly cellulose and hemicellulose (VAN SOEST, 1994).

The lowest NDF content of silages were obtained at $57 \mathrm{DAS}$, from that age, there was an increase in levels of pearl millet genotypes. Only the ADR 7010 showed similar content on the cuts ages of 57 and 65 DAS (Table 3). This increase in NDF content is due to the increase in cell wall constituents, making the plant more fibrous and less digestible. Low levels of fiber are desirable because, according to Van Soest (1994), the reduction in forage fiber enables improvements in consumption and digestibility due to NDF is correlated with consumption, which suggests that the silage harvested at 57 DAS may offer better conditions for consumption of silage harvested at 65 and 73 DAS.

The ADF of LAB 0730 silage harvested at 57 and 65 DAS were similar, differing only for silage harvested at $73 \mathrm{DAS}$. As for the other genotypes, the only difference was between the ages of 57 and 73 DAS, where there was an increase in ADF content (Table 3). According to Van Soest (1994), ADF is negatively correlated with forage digestibility, which favors genotypes of pearl millet harvested at 57 and 65 DAS, for having the lowest levels of ADF in silage. Noller, Nascimento Junior and Queiroz (1996), indicate that forages with ADF around 30\% or less will be consumed at high levels, while those with levels above $40 \%$ will be consumed at low levels.

Studying the quality and nutritive value of three cultivars of millet at different cutting ages, Amaral et al. (2008), found that there was significant interaction between cultivars and harvest ages, where the average of ADF were 39.51, 41.54 and 40.88 for ages 70,90 and 110 days respectively.

The same behavior for NDF and ADF was observed for lignin. The lower levels were obtained in silage harvested at 57 DAS, differentiating of silages harvested at 65 and 73 DAS. Only the LAB 7010 showed similar content on the cuts ages of 65 and 73 of DAS. Low concentrations of lignin is considered relevant to improving the nutritional value of forage and increased consumption of silage by animals, because the lignin is associated with indigestible food, however, more important than its content is its structural arrangement in the cell wall forage (JUNG; DEETZ, 1993). However, there have been approached the lignin content in tropical grasses as depressive fraction of food (LEONEL et al., 2009), therefore, low levels of lignin allow better use of the fiber by microorganisms in the rumen (RIBEIRO et al., 2008). 
Table 3. Neutral detergent fiber (NDF), acid detergent fiber (ADF), lignin, cellulose and hemicellulose content of millet genotypes ensiled with three different cuts ages.

\begin{tabular}{|c|c|c|c|}
\hline \multirow{2}{*}{ Millet Genotypes } & \multicolumn{3}{|c|}{ Cuts Ages (DAS) } \\
\hline & 57 & 65 & 73 \\
\hline & \multicolumn{3}{|c|}{ Neutral detergent fiber content $(\%)$} \\
\hline ADR 500 & $59.00 \mathrm{c}$ & $62.66 \mathrm{~b}$ & $69.65 \mathrm{a}$ \\
\hline ADR 7010 & $60.33 \mathrm{~b}$ & $62.00 \mathrm{~b}$ & $69.66 \mathrm{a}$ \\
\hline LAB 0730 & $56.65 \mathrm{c}$ & $63.34 \mathrm{~b}$ & $67.07 \mathrm{a}$ \\
\hline LAB 0731 & $60.32 \mathrm{c}$ & $64.63 \mathrm{~b}$ & $69.33 \mathrm{c}$ \\
\hline LAB 0732 & $60.44 \mathrm{c}$ & $64.67 \mathrm{~b}$ & $69.35 \mathrm{c}$ \\
\hline Average & 59.34 & 63.46 & 69.01 \\
\hline \multirow[t]{2}{*}{ CV $(\%)$} & \multicolumn{3}{|c|}{ 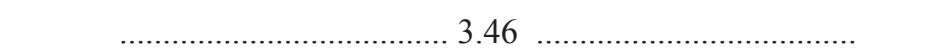 } \\
\hline & \multicolumn{3}{|c|}{ Acid detergent fiber content $(\%)$} \\
\hline ADR 500 & $36.33 \mathrm{~b}$ & $39.32 \mathrm{ab}$ & $40.65 \mathrm{a}$ \\
\hline ADR 7010 & $38.65 \mathrm{~b}$ & $39.64 \mathrm{ab}$ & $43.32 \mathrm{a}$ \\
\hline LAB 0730 & $37.66 \mathrm{~b}$ & $37.32 \mathrm{~b}$ & $44.08 \mathrm{a}$ \\
\hline LAB 0731 & $38.06 \mathrm{~b}$ & $42.00 \mathrm{ab}$ & $45.67 \mathrm{a}$ \\
\hline LAB 0732 & $38.00 \mathrm{~b}$ & $42.10 \mathrm{ab}$ & $45.65 \mathrm{~b}$ \\
\hline Average & 37.74 & 40.07 & 43.87 \\
\hline \multirow[t]{2}{*}{$\mathrm{CV}(\%)$} & \multirow{2}{*}{\multicolumn{3}{|c|}{ 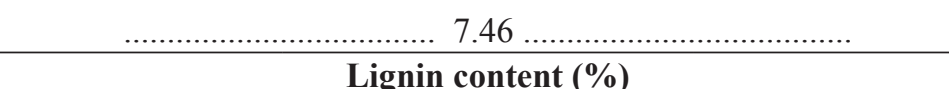 }} \\
\hline & & & \\
\hline ADR 500 & $6.20 \mathrm{c}$ & $7.76 \mathrm{~b}$ & $9.13 \mathrm{a}$ \\
\hline ADR 7010 & $6.06 \mathrm{~b}$ & $8.13 \mathrm{a}$ & $8.86 \mathrm{a}$ \\
\hline LAB 0730 & $5.53 \mathrm{c}$ & $7.80 \mathrm{~b}$ & $9.26 \mathrm{a}$ \\
\hline LAB 0731 & $5.90 \mathrm{c}$ & $7.73 \mathrm{~b}$ & $9.16 \mathrm{a}$ \\
\hline LAB 0732 & $6.86 \mathrm{c}$ & $8.36 \mathrm{~b}$ & $10.12 \mathrm{a}$ \\
\hline Average & 6.11 & 7.95 & 9.30 \\
\hline \multirow[t]{2}{*}{ CV $(\%)$} & & $.0 .01 \ldots \ldots$ & \\
\hline & \multicolumn{3}{|c|}{ Cellulose content $(\%)$} \\
\hline ADR 500 & $30.20 \mathrm{a}$ & $31.43 \mathrm{a}$ & $31.46 \mathrm{a}$ \\
\hline ADR 7010 & $32.80 \mathrm{a}$ & $32.89 \mathrm{a}$ & $34.03 \mathrm{a}$ \\
\hline LAB 0730 & $29.40 \mathrm{~b}$ & $32.00 \mathrm{ab}$ & $34.53 \mathrm{a}$ \\
\hline LAB 0731 & $32.40 \mathrm{~b}$ & $34.26 \mathrm{ab}$ & $36.36 \mathrm{a}$ \\
\hline LAB 0732 & $31.43 \mathrm{~b}$ & $33.63 \mathrm{ab}$ & $35.33 \mathrm{a}$ \\
\hline Average & 31.24 & 32.84 & 34.34 \\
\hline \multirow[t]{2}{*}{ CV $(\%)$} & \multicolumn{3}{|c|}{ 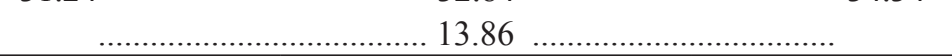 } \\
\hline & \multicolumn{3}{|c|}{ Hemicellulose content $(\%)$} \\
\hline ADR 500 & $22.32 \mathrm{~b}$ & $23.33 \mathrm{~b}$ & $29.04 \mathrm{a}$ \\
\hline ADR 7010 & $21.65 \mathrm{~b}$ & $22.66 \mathrm{ab}$ & $27.00 \mathrm{a}$ \\
\hline LAB 0730 & $19.00 \mathrm{~b}$ & $24.06 \mathrm{a}$ & $26.10 \mathrm{a}$ \\
\hline LAB 0731 & $22.23 \mathrm{~b}$ & $22.65 \mathrm{~b}$ & $24.07 \mathrm{~b}$ \\
\hline LAB 0732 & $22.34 \mathrm{~b}$ & $22.68 \mathrm{~b}$ & $24.12 b$ \\
\hline Average & 21.50 & 23.07 & 26.06 \\
\hline $\mathrm{CV}(\%)$ & (2) & 13.86 & \\
\hline
\end{tabular}

Means followed by different letters with lower case in line (age cuts), differs by Tukey test $(\mathrm{P}<0.05)$.

Source: Elaboration of the authors. 
Guimarães Junior (2005a) evaluating the fibrous fractions of silages of three pearl millet genotypes, observed lignin concentration of 4.01, 3.34 and $4.31 \%$ for the CMS-1; BRS-1501 and BN-2 genotypes, respectively, after the fermentation period of 56 days. These levels were lower than those found in this study.

It is observed in Table 3 that the levels of cellulose for silage harvested at different ages were similar to ADR 500 and ADR 7010. Just for LAB 0730, 0731 and 0732 the cuts ages were different, where the highest levels of cellulose were obtained at 73 DAS.

Regardless of the evaluated genotypes the average of cellulose levels were $31.24,32.84$ and $34.34 \%$ for the cuts ages of 57, 65 and 73 DAS, respectively. These results were superior to those found by Guimarães Junior (2005a) in the silages from CMS-1, BRS-1501 and BN-2 genotypes, obtained at 56 days of fermentation.

The hemicellulose is known as a reserve carbohydrate and a potential source of energy for microorganisms in the rumen. It is considered the main source of additional substrate for silage fermentation, could be consumed from $40 \%$ to $50 \%$ by microorganisms found in the ensilage process (HENDERSON, 1993).

In the hemicellulose fraction, there was also an increase in fiber with the addition of cutting ages. Silages from ADR 500, LAB 0731 and 0732 genotypes showed significantly lower levels at the ages of 57 and 65 DAS. As for ADR 1070 and 0730 LAB there was a difference for hemicellulose values only when silages were harvested at 57 and 73 DAS (Table 3). Costa et al. (2007) reported that the greatest changes occurring in the chemical composition of forage plants are those arising from its maturity, because, as the forage matures, the production of potentially digestible components tends to decrease the proportion of lignin, cellulose, hemicellulose and other indigestible fractions increase, leading to a decrease in digestibility.

\section{Conclusions}

The results showed that the silages produced by millet, regardless of genotype, could be considered of nutritional value.

Since this is a precocious material the best age that provided the best quality of these silages was when materials were harvested at 57 DAS.

\section{References}

AMARAL, P. N. C.; EVANGELISTA, A. R.; SALVADOR, F. M.; PINTO, J. C. Qualidade e valor nutritivo da silagem de três cultivares de milheto. Ciência e Agrotecnologia, Lavras, v. 32, n. 2, p. 611-617, 2008.

BORGES, A. L. C. C.; GONÇALVES, L. C.; RODRIGUEZ, N. M. Silagem de sorgo de porte alto com diferentes teores de tanino e de umidade no colmo. I - Teores de matéria seca, $\mathrm{pH}$ e ácidos graxos durante a fermentação. Arquivo Brasileiro de Medicina Veterinária e Zootecnia, Belo Horizonte, v. 49, n. 6, p. 719-732, 1997.

CAPPELLE, E. R.; VALADARES FILHO, S. C.; SILVA, J. F. C.; CECON, P. R. Estimativas do valor energético a partir de características químicas e bromatológicas dos alimentos. Revista Brasileira de Zootecnia, Viçosa, v. 30, n. 6, p. 1837-1856, 2001.

CHANDLER, P. Energy prediction of feeds by forage testing explorer. Feedstuffs, Bloomington, v. 62, n. 36, p. $12,1990$.

COSTA, K. A. P.; OLIVEIRA, I. P.; FAQUIN, V.; NEVES, B. P.; RODRIGUES, C.; SAMPAIO, F. M. T. Intervalo de corte na produção de massa seca e composição químico-bromatológica da Brachiaria brizantha cv. MG-5. Ciência e Agrotecnologia, Lavras, v. 31, n. 4, p. 1197-1202, 2007.

DAN, H. A.; BARROSO, A. L. L.; GOMES, L.; TANNÚS, V. R.; FINOTTI, T. R. Seletividade de herbicidas aplicados na pós-emergência da cultura do milheto (Pennisetum Glaucum). Revista Brasileira de Milho e Sorgo, Sete Lagoas, v. 8, n. 3, p. 297-306, 2009.

FERREIRA, D. F. Análises estatísticas por meio do Sisvar para Windows versão 4.0. In: Reunião Anual da Região Brasileira da Sociedade internacional de Biometria. UFSCar, São Carlos, 2000. p. 255-258.

GUIMARÃES JUNIOR, R.; GONÇALVES, L. C.; RODRIGUES, J. A. S.; BORGES, A. L. C. C.; RODRIGUEZ, N. M.; SALIBA, E. O. S.; BORGES, 
I.; PIRES, D. A. A.; JAYME, D. G.; CASTRO, G. H. F. Frações fibrosas dos materiais originais e das silagens de três genótipos de milheto [Pennisetum glaucum (1). r. br.], em diferentes períodos de fermentação. Revista Brasileira de Milho e Sorgo, Sete Lagoas, v. 4, n. 2, p. 243-250, 2005a.

GUIMARÃES JUNIOR, R.; GONÇALVES, L. C.; MAURÍCIO, R. M.; PEREIRA, L. G. R.; TOMICH, T. R.; PIRES, D. A. A.; JAYME, D. G.; SOUSA, L. F. Cinética de fermentação ruminal de silagens de milheto. Arquivo Brasileiro de Medicina Veterinária de Zootecnia, Belo Horizonte, v. 60, n. 5, p. 1174-1180, 2008.

GUIMARÃES JUNIOR, R.; GONÇALVES, L. C.; SANTOS, J. A.; JAYME, D. G.; PIRES, D. A. A.; BORGES, A. L. C. C.; RODRIGUEZ, N. M.; SALIBA, E. O. S.; BORGES, I. R. Matéria seca, proteína bruta, nitrogênio amoniacal e $\mathrm{pH}$ das silagens de três genótipos de milheto [Pennisetum glaucum (1). r. br.] em diferentes períodos de fermentação. Revista Brasileira de Milho e Sorgo, Sete Lagoas, v. 4, n. 2, p. 251-258, 2005b.

GUIMARÃES JUNIOR, R.; GONÇALVES, L. C.; SANTOS, J. A.; RODRIGUEZ, N. M.; BORGES, A. L. C. C.; BORGES, I. R.; SALIBA, E. O. S.; JAYME, D. G.; PIRES, D. A. A. Carboidratos solúveis, digestibilidade "in vitro" da matéria seca e ácidos orgânicos das silagens de três genótipos de milheto [pennisetum glaucum (1). r. br.] em diferentes períodos de fermentação. Revista Brasileira de Milho e Sorgo, Sete Lagoas, v. 4, n. 1, p. 95-103, 2005c.

HENDERSON, N. Silage additives. Animal Feed Science Technology, Amsterdam, v. 45, n. 1, p. 35-56, 1993.

JAYME, C. G.; MOLINA, L. R.; GONÇALVES, L. C.; JAYME, D. G.; PIRES, D. A. A.; BORGES, I. Determinação do momento de colheita da Brachiaria brizantha (hochest.) stapf. cv. Marandu para produção de silagem. Ciência e Agrotecnologia, Lavras, v. 33, n. 2, p. 586-591, 2009.
JUNG, H. G.; DEETZ, D. A. Cell wall lignification and degradability. In: JUNG, H. G.; BUXTON, D. R.; HATFIELD, R. D. et al. (Ed.). Forage cell wall structure and digestibility. Madison: ASA/CSSA/SSSA, 1993. p. 315-346.

LEONEL, F. P. L.; PEREIRA, J. C.; COSTA, M. G.; MARCO JÚNIOR, P.; da SILVA, C. J.; LARA, L. A. Consórcio capim-braquiária e milho: comportamento produtivo das culturas e características nutricionais e qualitativas das silagens. Revista Brasileira de Zootecnia, Viçosa, v. 38, n. 1, p. 166-176, 2009.

McDONALD, P.; HENDERSON, A. R.; HERON, S. J. E. The biochemistry of silage. 2. ed. Bucks: Chalcombe Publications, 1991. $340 \mathrm{p}$.

NOLLER, C. H.; NASCIMENTO JUNIOR, D.; QUEIROZ, D. S. Exigências nutricionais de animais em pastejo. In: SIMPÓSIO SOBRE O MANEJO DAS PASTAGENS, 13., 1996, Piracicaba. Anais... Piracicaba: FEALQ. 1996. p. 319-352.

NUSSIO, L. G.; CAMPOS, F. P.; DIAS, F. N. Importância da qualidade da porção vegetativa no valor alimentício da silagem de milho. In: SIMPÓSIO SOBRE PRODUÇÃO E UTILIZAÇÃO DE FORRAGENS CONSERVADAS, 1., 2001, Maringá. Anais... Maringá: UEM, 2001. p. 319.

RIBEIRO, X. R. R.; OLIVEIRA, R. L.; BAGALDO, A. R.; FARIA, E. F. S.; GARCEZ NETO, A. F.; SILVA, T. M.; BORJA, M. S.; CARDOSO NETO, B. M. Capimtanzânia ensilado com níveis de farelo de trigo. Revista Brasileira de Saúde e Produção Animal, Salvador, v. 9, n. 4, p. 631-640, 2008.

SILVA, D. J.; QUEIROZ, A. C. Análise de alimentos (métodos químicos e biológicos). 3. ed. Viçosa: Imprensa Universitária da UFV, 2002. 235 p.

VAN SOEST, P. J. Nutritional ecology of the ruminant. 2. ed. Ithaca: Cornell University Press, 1994. 476 p. 
